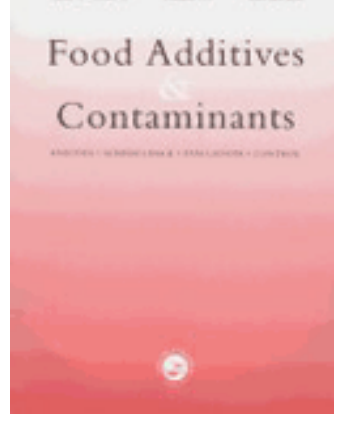

\title{
Development of an LC-MS/MS method for the determination of pesticides and patulin in apples.
}

\begin{tabular}{|r|l|}
\hline Journal: & Food Additives and Contaminants \\
\hline Manuscript ID: & TFAC-2008-266.R1 \\
\hline Manuscript Type: & Original Research Paper \\
\hline Author: & 06-Feb-2009 \\
\hline Complete List of Authors: & $\begin{array}{l}\text { Christensen, Hanne; National Food Institute, Technical University of } \\
\text { Denmark } \\
\text { Poulsen, Mette; National Food Institute, Technical University of } \\
\text { Denmark } \\
\text { Rasmussen, Peter; National Food Institute, Technical University of } \\
\text { Denmark } \\
\text { Christen, Danilo; Agroscope Changins-Wädenswil Research Station } \\
\text { ACW }\end{array}$ \\
\hline Methods/Techniques: & Chromatography - LC/MS \\
\hline Additives/Contaminants: & Mycotoxins, Pesticide residues \\
\hline Food Types: & Fruit \\
\hline
\end{tabular}

\section{SCHOLARONE" Manuscripts}




\begin{abstract}
A method for the simultaneous determination of 33 pesticides or degradation products together with patulin in apples by LC-MS/MS was developed. The method involved homogenisation of the apples, extraction with ammonium acetate-acetic acid solution in methanol-water by ultrasonication, filtration and determination by LC-MS/MS. The repeatability and within-laboratory reproducibility for the three spiking levels $0.02,0.04$ and $0.2 \mathrm{mg} \mathrm{kg}^{-1}$ were between 4 and $35 \%$. In general, the repeatability and reproducibility were about 10-20\%. The limits of quantification (LOQs) were between $0.01-0.14 \mathrm{mg} \mathrm{kg}^{-1}$. The method was used on incurred samples from parts of the ISAFRUIT project financed by the European Commission under the $6^{\text {th }}$ Framework Programme. Samples were analysed at four different stages, after harvest, after storage (controlled), after water bath and after 28 days at room temperature. Pesticide residues were found at all stages, but no significant differences in the concentration were seen between the stages analysed. The concentration decreased significantly only for tolylfluanid after storage at room temperature for 28 days when only $0-6 \%$ of the original amount of tolylfluanid remained in the apples. . No patulin was found in the apples stored for 28 days at room temperature and no growth of P. expansum was observed on these apples. However, when the apples were inoculated with a spore suspension of $P$. expansum high concentrations of patulin were found.
\end{abstract}

Keywords: apples, pesticides, patulin, Penicillium expansum, LC-MS/MS.

\title{
Introduction
}

Pesticides are widely used in the production of apples, both pre- and post-harvest to protect the apples from a range of pests and fungi, but also to preserve quality. Food Authorities such as the European Commission (EC) have established Maximum Residue Levels (MRLs) for the majority of the pesticides used in the production of apples (European Community, 2006). Monitoring programmes for pesticides have shown that fungicides and insecticides are often found in apples. In $59 \%$ of apple samples analysed in the EC coordinated monitoring programme for 2004 pesticide residues were found (European Commission, 2004). Although, residues above the MRLs were 
found only in $2 \%$ of the samples, many consumers are nevertheless concerned about exposure to pesticide residues.

Several fungi can produce mycotoxins either in the field or during storage, and especially for apples Penicillium expansum is by far the most dominant fungal species. P. expansum is a known producer of patulin, and the European Communities (EC), have introduced a maximum limit of $50 \mu \mathrm{g} \mathrm{kg}^{-1}$, for patulin content in apple juice and other apple products (European Commission, 2003). Furthermore, P. expansum spoilage of and hence patulin content in apples is a well known problem for the apple juice industry as apples are commonly stored prior to production due to processing capacity limitations. Patulin is therefore often used as an indicator of the use of poor quality raw materials in juice manufacture (Pitt, 2002). The analytical methods for the determination of patulin in fruit and vegetables have often been carried out by methods dedicated to a single analyte, where HPLC with UV detection is commonly employed (Iha and Sabino, 2006; MacDonald et al., 2000).

Commonly, pesticide residues have been detected by so called multi-residue methods that cover several hundred compounds. However, risk assessment involving different contaminant groups have necessitated multi-residue methods covering different compound groups. No previous published papers have, to the authors knowledge, described the simultaneously determination of pesticides and mycotoxins in apples.

In the present study an integrated method for sample preparation, extraction and determination was developed for the simultaneous analysis of several pesticides together with patulin. The method was used especially, to identify the critical steps for chemical contaminants in the chain from orchard to consumer. Results from apples analysed after harvest, storage, grading and after shelf life are presented. The study was part of the European Integrated Research Project, ISAFRUIT that focuses on all aspects of fruit. It was financed via the $6^{\text {th }}$ Framework Programme (Thematic Priority 5 Food Quality and Safety). For more information on the project see the website, www.isafruit.org

\section{Materials and Methods}

\section{Field trials}

An experiment with the apple variety Malus Domestica (Golden delicious) to simulate the chain from orchard to consumers was performed at Agroscope Wadenswill (Switzerland). The apples were treated with the fungicides, trifloxystrobin, flusilazole, pirimicarb and thiacloprid at different application times (see Table 1). For the fungicide tolylfluanid four different application times were used in order to achieve different concentrations of the residue. Samples were collected at four 
critical points to simulate the chain from producer to consumer. The four points were 1) after harvest, 2) after storage for 6 month at $4^{\circ} \mathrm{C}$ in controlled atmosphere with low oxygen concentration, 3) after grading (here represented as a warm water bath at $30^{\circ} \mathrm{C}$ for $10 \mathrm{~min}$ ) performed the day that the apples were taken out of storage and 4) after 28 days shelf life at room temperature to simulate the consumers table.

\section{[insert table 1]}

Samples of $1 \mathrm{~kg}$ and at least 10 apples were collected from each group (1-4) and send to the laboratory at the National Food Institute, Technical University of Denmark, Denmark. Analysis was performed on samples collected at the four above mentioned critical point in the chain. See table 2 . The samples were packed in polyethylene bags and transported as quickly as possible to avoid any degradation during transportation.

[insert table 2]

\section{Incubation of apples with P. expansum}

The $P$. expansum isolate, IBT number 23732 , the type culture used in this study, was obtained from the Fungal Culture Collection (IBT collection) at the Department of Systems Biology, Technical University of Denmark, Denmark. The apples were divided into three groups of 10 apples (replicates). Group A was untreated, group B was surface inoculated with P. expansum and group C was inoculated in the core with $P$. expansum. The surface inoculated apples were stab wounded with a sterilised needle (4-5 mm wound) and $10 \mu \mathrm{l}$ of spore suspension $\left(>10^{6}\right.$ spores $\left.\mathrm{ml}^{-1}\right)$ was put on the wound. Core inoculated apples were inoculated through the flower opening via a syringe and $10 \mu \mathrm{l}$ of spore suspension $\left(>10^{6}\right.$ spores $\mathrm{ml}^{-1}$ ) was injected. The apples were incubated at room temperature for 28 days.

\section{Materials and instruments}

\section{Chemicals}

The pesticide standards (with certified purities $>96 \%$ ) were purchased from Dr. Ehrenstorfer (Augsburg, Germany) and the ${ }^{13} \mathrm{C}_{6}$-carbaryl (purity 99\%) from Cambridge Isotope Labs. (MA, USA). The patulin was purchased from Sigma Aldrich (USA). The methanol p.a. was from Fisher Scientific (Leichestershire, UK). Acetic acid and ammonium acetate were from Merck (Darmstadt, Germany). Mini Uniprep polypropylene filter vials $500 \mu 1$, pore size $0.45 \mu \mathrm{m}$ was purchased from Whatman (Kent, UK). The water used was Milli-Q water (Millipore, Bedford, MA, USA). 
Stock solutions of pesticides and patulin of $1 \mathrm{mg} \mathrm{ml}^{-1}$ were prepared in methanol and kept at $-18^{\circ} \mathrm{C}$. A standard mixture of $10 \mu \mathrm{g} \mathrm{ml}^{-1}$ in methanol was prepared from the stock solutions. Matrixmatched standards in the concentration range from 0.0015 to $0.05 \mu \mathrm{g} \mathrm{ml}^{-1}\left(0.007-0.24 \mathrm{mg} \mathrm{kg}^{-1}\right.$ matrix) were prepared by diluting the $10 \mu \mathrm{g} \mathrm{ml}^{-1}$ mixture with sample extracts of the relevant commodities bought as organically grown. The sample extracts were in the extraction solution: ammonium acetate / acetic acid $20 \mathrm{mM}$ in methanol-water (95:5), which is the same solution as eluent B.

\section{Sample preparation}

The apples were homogenised by a chopper (Weisser, Obersasbach, Germany). $10 \mathrm{~g}$ of sample was extracted with $40 \mathrm{ml}$ ammonium acetate-acetic acid solution $20 \mathrm{mM}$ in methanol-water (95:5) in an ultrasonic bath (Branson 5510, Soest, The Netherlands) for 30 minutes. The samples were centrifuged at $3500 \mathrm{rpm}$ for $10 \mathrm{~min}$ (Heraeus Sepatech Megafuge 3.0R, Osterode, Germany). Extracts, $400 \mu 1$, were transferred to Miniprep filter HPLC vials and added $40 \mu 1$ internal standard: ${ }^{13} \mathrm{C}_{6}$-carbaryl $0.1 \mu \mathrm{g} \mathrm{ml}^{-1}$ before filtration.

\section{Instrumentation and chromatographic conditions}

The LC system consisted of a HP1100 liquid chromatograph (Agilent Technologies, Palo Alto, CA, USA) equipped with a vacuum degasser, a solvent delivery compartment with high pressure mixing, an autosampler and a column compartment. The injection volume was $10 \mu 1$. Separation of pesticides was performed on a Genesis $C_{18}$ column, $100 \mathrm{~mm} \times 3 \mathrm{~mm}, 4 \mu \mathrm{m}$ particle size, (Gracevydac, Hengoed, UK). In front of the separation column was a Phenomenex SecurityGuard column, $\mathrm{C}_{18}$ ODS, $4 \mathrm{~mm} \times 2 \mathrm{~mm}$ (Cheshire, UK). The total flow rate of eluent A (ammonium acetate-acetic acid $20 \mathrm{mM}$ in MilliQ water) and B (ammonium acetate-acetic acid $20 \mathrm{mM}$ in methanol-MilliQ water (95:5)) was $0.3 \mathrm{ml} \mathrm{min}^{-1}$. The initial gradient was $100 \% \mathrm{~A}$, decreasing to $50 \% \mathrm{~A}$ after $2 \mathrm{~min}$ and $0 \% \mathrm{~A}$ after $20 \mathrm{~min}$. A was held at $0 \%$ until $24 \mathrm{~min}$. The total run time was $30 \mathrm{~min}$.

The MS-MS detection was performed on a Quattro Ultima triple quadrupole instrument (Micromass Manchester, UK) equipped with an atmospheric pressure ionisation (API) interface. The mass spectrometer was operated with electrospray both in the positive and the negative ion mode (ESI+ and ESI-). The capillary voltage was set to $1.0 \mathrm{kV}$. The source temperature was $120{ }^{\circ} \mathrm{C}$ and the desolvation temperature $350{ }^{\circ} \mathrm{C}$. Nitrogen was used as desolvation gas (flow $550 \mathrm{~h}^{-1}$ ) and cone gas (flow $50 \mathrm{l} \mathrm{h}^{-1}$ ), and argon was used as collision gas at a pressure of $1.7 \times 10^{-3}$ mbar. 


\section{Results and discussion}

\section{Method Validation}

The pesticides included in the method was chosen due to the possible use on apples. The accuracy of a method can be estimated from certified reference material, recoveries of spiked samples or from accuracy in proficiency testing. Recoveries were obtained by fortifying blank apple samples with pesticides and patulin. The majority of the pesticides, 30, were validated according to Document SANCO/2007/3131 (European Commission, 2007). The mean recoveries of the pesticides $(n=6)$ at the spiking levels $0.02,0.04$ and $0.2 \mathrm{mg} \mathrm{kg}^{-1}$ appears from Table 4. For most pesticides recoveries were within $70-110 \%$. For the three pesticides trifloxystrobin, tolylfluanid, thiacloprid and for patulin, the determination of the accuracy consisted in recovery test at the three spiking levels, $0.02,0.04$ and $0.2 \mathrm{mg} \mathrm{kg}^{-1}$, single determination with three repetitions (four repetitions for patulin). Again the mean recovery was between $69-109 \%$, see table 5 .

[insert table 4]

[inset table 5]

\section{Precision}

For the 30 pesticides or degradation products, the repeatability and within laboratory reproducibility were calculated according to ISO5725-2 [Anon, 1994] using duplicate determinations for calculations of repeatability and the repetitions for calculation of reproducibility. The repeatability, $\mathrm{RSD}_{\mathrm{r}}$, and reproducibility, $\mathrm{RSD}_{\mathrm{R}}$, for the three spiking levels $0.02,0.04$ and $0.2 \mathrm{mg} \mathrm{kg}^{-1}$ is shown in Table 4. No significant differences were seen between the spiking levels. In general, the repeatability and reproducibility were about $10-20 \%$, which is acceptable for multi-residue methods. For trifloxystrobin, tolylfluanid, thiacloprid the standard deviation between the recovery series were in the range of $4-26 \%$ (see table 5).

\section{Limits of quantification.}


The limit of quantification (LOQ) was calculated as 6 times the standard deviation of the absolute recoveries at the lowest accepted spiking level. The LOQ's are given in table 4 for the 46 pesticides, and table 5 for the three pesticides and patulin.

Quantification was performed for each analytical series using means of two 5-point calibration curves. The matrix matched calibrations standards were of the concentrations $0.0015,0.003,0.01$, 0.025 and $0.05 \mu \mathrm{g} \mathrm{ml}^{-1}$. The linearity of the calibration curves were $\mathrm{r} 2>0.99$. Chromatograms of field treated samples are shown in figure 1.

[insert figure 1]

\section{Result from apples sampled along the artificial chain from producer to consumer.}

The validated method was used for the analysis of 64 samples collected from an artificial chain from producer to consumer, described above under Method. Thiacloprid was not found in any of the samples, however this may be due to the fact that thiacloprid was only applied once 90 days before harvest, which may lead to residue content below the detection limit. Patulin was expected only to be present in the samples analysed after 28 days at room temperature and therefore only analysed for in these 16 samples.

No patulin was found in the apple samples analysed after 28 days at room temperature. But to verify the capability of the method, it was used to analyse samples inoculated with $P$. expansum. The results of these samples are presented below.

\section{Pesticides}

Trifloxystrobin, flusilazole and pirimicarb were found in low concentrations from 0.006-0.024 mg $\mathrm{kg}^{-1}$. These pesticides were applied more than 50 days before harvest and the low levels were expected. No significant differences in the concentration were seen in the samples after harvest, after storage, after grading and samples after 28 days shelf life, see Figure 2. However, due to the low concentrations it may be difficult to see any decrease in the concentration through the chain.

[insert Figure 2 here] 
For tolylfluanid the concentrations were between $0.016-0.488 \mathrm{mg} \mathrm{kg}^{-1}$. The results are shown in Figure 3. The highest concentrations were found in the samples sprayed seven days before harvest. The concentrations found in the samples sprayed 4 weeks before harvest were at the same levels as the tolylfluanid untreated apples. The reasons for the finding of tolylfluanid residues in the untreated samples are supposed to arise from drift of pesticides during spraying. The concentration of the tolylfluanid residue found in the samples collected after harvest were 4-6 times lower than the concentration after storage. According to the Pesticide Manual (Tomlin, 2006), tolylfluanid is rapidly hydrolysed into dimethylamino sulfotoluidide (DMST). The explanation of the low levels in the apples collected after harvest could be that tolylfluanid in the apples were degraded due to exposure to light, heat and moisture during transportation.. These factors were better controlled by wrapping the apples during transportation.The wrapping was consequently improved when next batch of samples were send to the laboratory and these apples arrived in very good condition. No significant decrease in tolylfluanid residues was seen after water bath. However, storage at room temperature in 28 days decreased the concentration significantly. No residues were found in the 28 days sample that had been sprayed four and two weeks before harvest. The concentration of tolylfluanid in the samples sprayed 1 week before harvest was $0.03 \mathrm{mg} \mathrm{kg}^{-1}$, which was a reduction of $94 \%$.

[insert Figure 3 here]

The results of pesticide residues from the critical point 2, 3 and 4 are in accordance with an investigation done by Rasmussen et al. (2003) on the effects of washing and storing two different sorts of apples. None of the pesticide included in that study was significantly reduced when the apples were subjected to simple washing. However, storing in a refrigerated room at $4^{\circ} \mathrm{C}$ for $42-79$ day significantly reduced 5 out of 13 pesticide residues, including tolylfluanid, which were reduced by $47-69 \%$.

\section{Patulin}

The patulin content and the growth of $P$. expansum in apples treated with pesticides at different times before harvest was investigated after 28 days of shelf-life (see Table 2 for more details).

As shown in Table 6 no patulin was found in the apple samples stored for 28 days at room temperature. Furthermore no growth of $P$. expansum was observed on these apples, showing that patulin producing fungi is not a problem in apple samples stored under the present incubation conditions. When the apples were inoculated by a spore suspension of $P$. expansum patulin had 
been produced at quite high levels in both core and surface inoculations exceeding the EU maximum limit of $50 \mu \mathrm{g} \mathrm{kg}^{-1}$ for apple juice with several hundred percent. In accordance with the study of Karlshøj et al. (2007), the patulin concentrations were 2 - 5 times higher in core inoculated apples compared to the surface inoculated apples. This was probably due to the higher degree of spoilage in these apples as the fungus was able to grow spherically in all directions from the core, whereas the surface inoculated colony was limited to hemispherical growth; that is, the patulin to hyphae ratio between the two types of infection is expected to be the same. It was not possible from the present results to evaluate or explain the effects of pesticide treatment carried at different periods before harvest.

[insert table 6 here]

\section{Conclusions}

A method for simultaneous determination of 33 pesticides or degradation products together with patulin in apples was developed. The repeatability and within laboratory reproducibility for the three spiking levels $0.02,0.04$ and $0.2 \mathrm{mg} \mathrm{kg}^{-1}$ were between $4-35 \%$. In general, the repeatability and reproducibility were about 10-20\%. The limits of detection (LODs) were between 0.01-0.14 $\mathrm{mg} \mathrm{kg}^{-1}$. The method was used for the determination of pesticide residues and patulin in samples from the ISAFRUIT project. Trifloxystrobin, flusilazole and pirimicarb were found in low concentrations from $0.006-0.024 \mathrm{mg} \mathrm{kg}^{-1}$. No significant differences in the concentration were seen in the samples after harvest, after storage, after grading and samples after 28 days shelf life. Tolylfluanid was found in concentrations between $0.016-0.488 \mathrm{mg} \mathrm{kg}^{-1}$. No significant decrease in tolylfluanid residues was seen after water bath. However, the storage in room temperature in 28 days decreased the concentration significantly with $94-100 \%$. No patulin was found in the apple samples stored for 28 days at room temperature and no growth of $P$. expansum was observed on these apples. However, patulin were produced in levels exceeding the EU maximum limit of $50 \mu \mathrm{g}$ $\mathrm{kg}^{-1}$ for apple juice, when the apples were inoculated with a spore suspension of $P$. expansum. The patulin concentrations were $2-5$ times higher in core inoculated apples compared to the surface inoculated apples.

\section{Acknowledgement}

We would like to thank the European Commission for financing the project (ISAFRUIT). We would also like to thank Merete B. Ludwigsen and Inge Schröder for the excellent technical skills. 


\section{Reference:}

Anon, 1994: Accuracy (Trueness and Precision) of Measurements Methods and Results-Part 2 (Geneva: ISO), 1994 (ISO 5725-2:1994).

European Commission Regulation (EC) No 1425/2003. Off J. Eur

European Commission, 2004, Pesticide monitoring reports;

http://ec.europa.eu/food/fvo/specialreports/pesticides_index_en.htm

European Commission, 2006; http://ec.europa.eu/food/plant/protection/pesticides/index_en.htm

European Commission, 2007. Method validation and quality control procedures for pesticide residue analysis in food and feed. SANCO/2007/3131. European Commission.

Granby, K; Andersen, J.H and Christensen, H.B (2004). Analysis of pesticides in fruit, vegetables and cereals using methanolic extraction and detection by liquid chromatography-tandem mass spectrometry. Analytica Chemica Acta 520: 164-176.

Iha, M.H. and Sabino, M. (2006). Determination of Patulin in applejuice by liqid chromatography. Journal of AOAC International, 89: 139-143.

Karlshøj K, Nielsen PV, Larsen TO. (2007). Prediction of Penicillium expansum spoilage and patulin concentration in apples used for apple juice production by electronic nose analysis. Journal of Agricultural and Food Chemistry (in press)

MacDonald S, Long M, Gilbert J. (2000). Liquid chromatography method for determination of patulin in clear and cloudy apple juices and apple puree: Collaborative study. Journal of AOAC International, 83:1387-1393.

Moukas, A.; Panagiotopoulou, V. and Markaki, P. (2008). Determination of patulin in fruit jjuices using HPLC-DAD and GC-MSD techniques. Food Chemistry, 109: 860-867. 
Pitt J.I. (2002). Biology and ecology of toxigenic Penicillium species. In:Mycotoxins and Food Safety, pp 29-41. Eds: DeVries JW, Truckness MW, Jackson LS. Kluwer Academic, New York, USA.

Rasmussen, R.R., Poulsen, M.E. and Hansen, H.C.B.(2003): Distribution of multiple pesticide residues in apple segments after home processing. Food Additives and Contaminants, 20, No. 11, pp. 1044-1063.

Tomlin CDS (ed) (2006-2007) The e-Pesticide manual, $14^{\text {th }}$ ed. British Crop Protection Council, London, UK. 
Figure 1. Examples of chromatogrammes of samples containing trifloxystrobin, pirimicarb, flusilazole, tolylfluanid, thiacloprid and patulin.

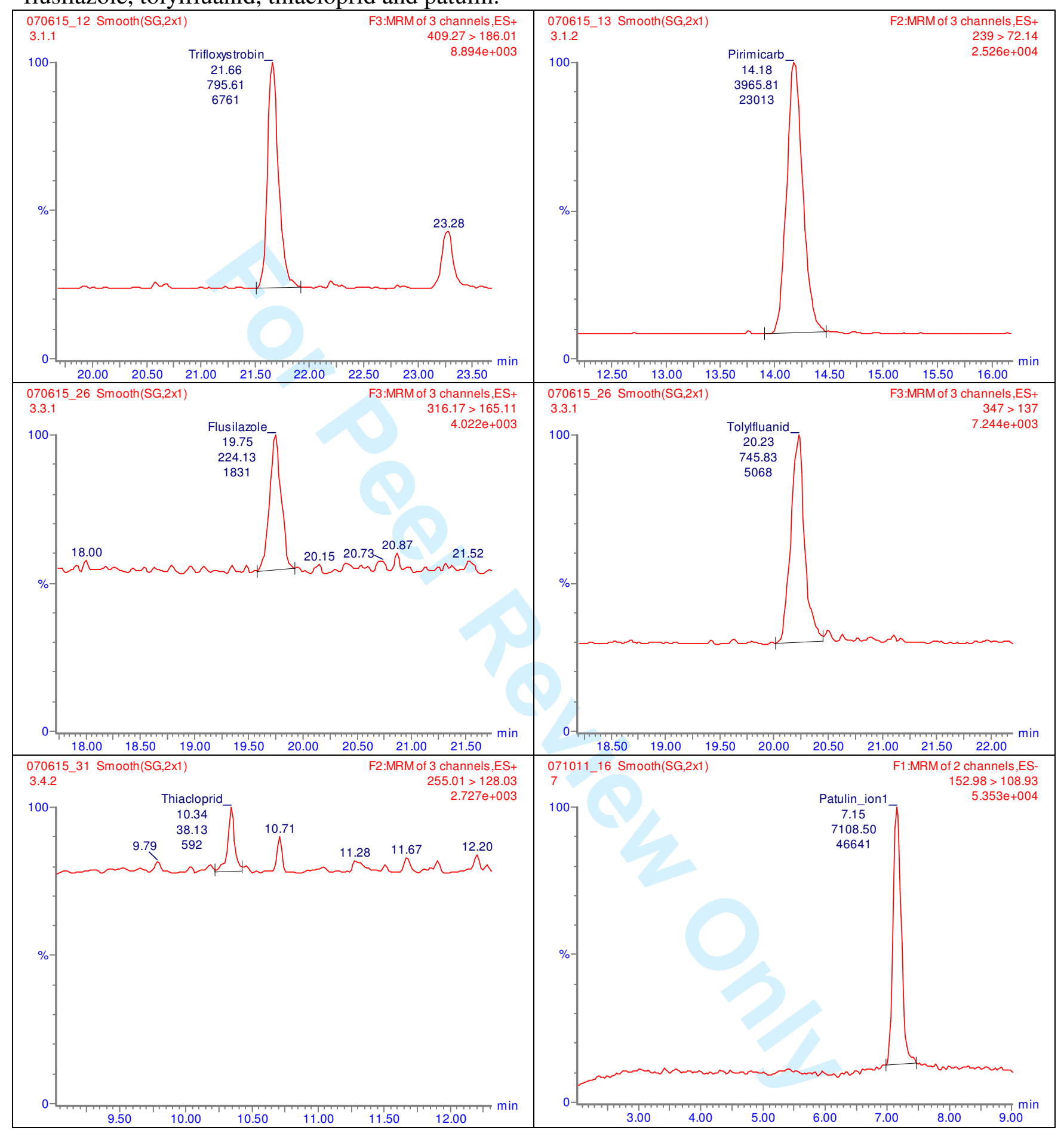




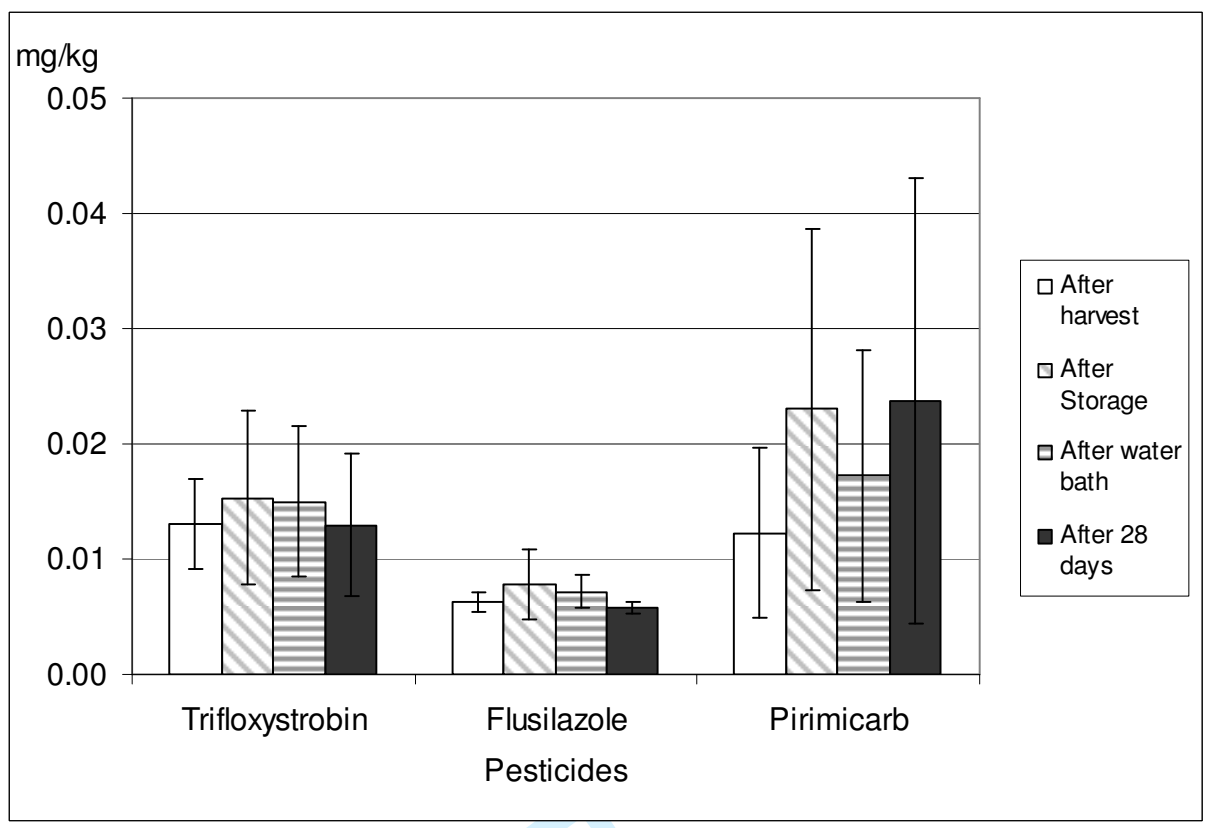

Figure 2. Residues of trifloxystrobin, flusilazole and pirimicarb in apples collected at the critical points along the artificial chain from producer to consumer. 


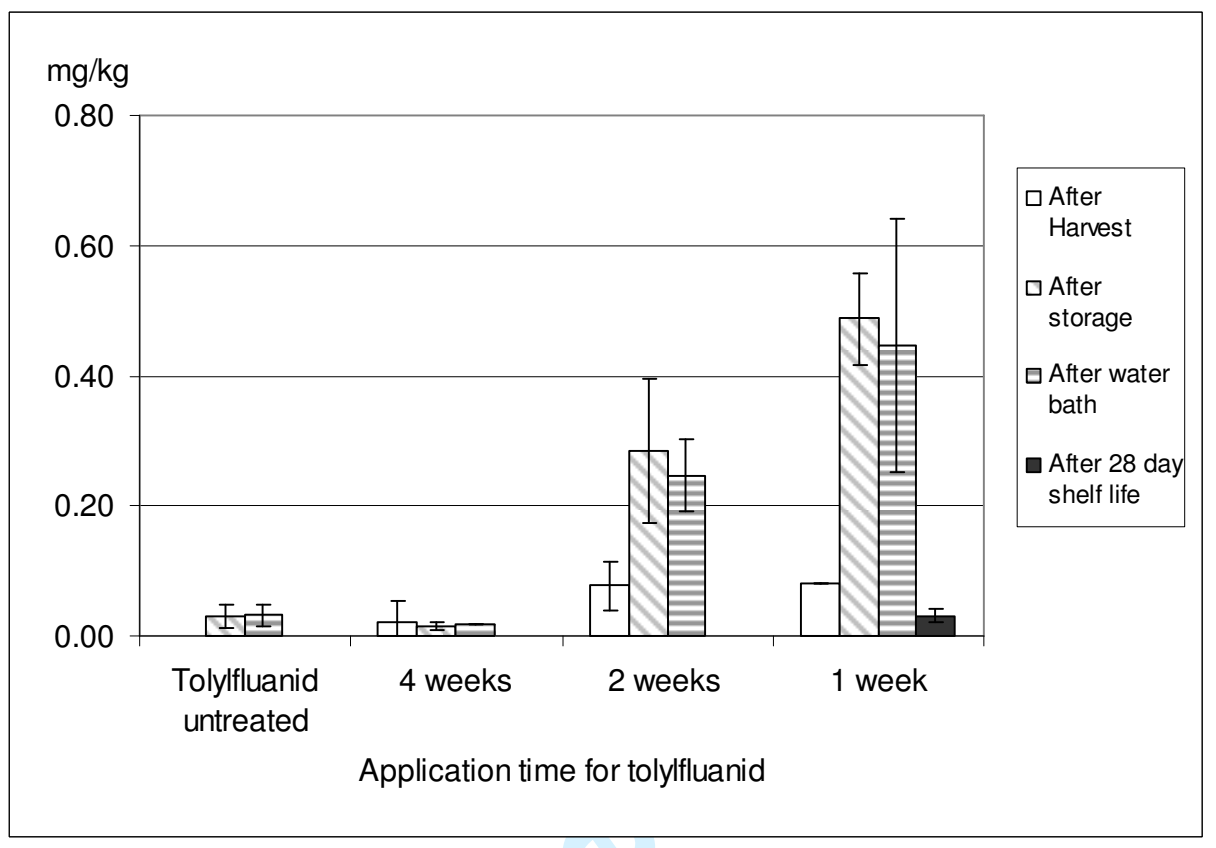

Figure 3. Residues of tolylfluanid in apples, applied at different time and collected at the critical points along the artificial chain from producer to consumer. 
Table 1. Application dates with the formulations and active substances used, apple group spayed and number of days from spraying to harvest

\begin{tabular}{|c|c|c|l|l|c|}
\hline $\begin{array}{c}\text { Application } \\
\text { no. }\end{array}$ & $\begin{array}{c}\text { Application } \\
\text { dates }\end{array}$ & $\begin{array}{c}\text { Apple group } \\
\text { sprayed }\end{array}$ & Formulations & \multicolumn{1}{|c|}{$\begin{array}{c}\text { Active } \\
\text { subtances }\end{array}$} & $\begin{array}{c}\text { No. of days } \\
\text { to harvest }\end{array}$ \\
\hline 1 & $26-05-2006$ & Group 1,2,3,4 & Flint & Trifloxystrobin & 112 \\
\hline 2 & $08-06-2006$ & Group 1,2,3,4 & Flint & Trifloxystrobin & 99 \\
\hline 3 & $17-06-2006$ & Group 1,2,3,4 & $\begin{array}{l}\text { Nustar } \\
\text { Alanto }\end{array}$ & $\begin{array}{l}\text { Flusilazole } \\
\text { Thiacloprid }\end{array}$ & 90 \\
\hline 4 & $29-06-2006$ & Group 1,2,3,4 & Nustar & Flusilazole & 78 \\
\hline 5 & $12-07-2006$ & Group 1,2,3,4 & Flint & Trifloxystrobin & 65 \\
\hline 6 & $26-07-2006$ & Group 1,2,3,4 & $\begin{array}{l}\text { Flint } \\
\text { Pirimor }\end{array}$ & $\begin{array}{l}\text { Trifloxystrobin } \\
\text { Pirimicarb }\end{array}$ & 51 \\
\hline 7 & $09-08-2006$ & Group 2 & $\begin{array}{l}\text { Euparene } \\
\text { Euparene }\end{array}$ & $\begin{array}{l}\text { Tolylfluanid } \\
\text { Tolylfluanid } \\
\text { Tolylfluanid }\end{array}$ & 37 \\
& $31-08-2006$ & Group 3 & $\begin{array}{l}\text { Euparene } \\
\text { Group 4 }\end{array}$ & 15 \\
\hline
\end{tabular}


Table 2. Schedule for sampling at critical point from the chain from orchard to consumer, group samples, number of samples and the analytical program performed

\begin{tabular}{|l|l|l|c|l|}
\hline \multicolumn{1}{|c|}{ Critical point } & \multicolumn{1}{|c|}{ Date } & Apple group & $\begin{array}{c}\text { Number of } \\
\text { samples }\end{array}$ & \multicolumn{1}{|c|}{ Analytical profile } \\
\hline 1) After harvest & 15 September 2006 & Group 1,2,3,4 & 4 & Pesticides \\
\hline $\begin{array}{l}\text { 2) After storage in CA } \\
\text { Controlled Atmosphere }\end{array}$ & 15 March 2007 & Group 1,2,3,4 & 4 & Pesticides \\
\hline 3) After grading/water bath & 15 March 2007 & Group 1,2,3,4 & 4 & Pesticides \\
\hline 4) After 28 days of shelf-life & 12 April 2006 & Group 1,2,3,4 & 4 & Pesticides and patulin \\
\hline
\end{tabular}


Table 3: Transitions for the validated pesticides and patulin.

\begin{tabular}{|c|c|c|c|c|c|c|c|c|c|c|}
\hline & & & & & & nsiti & & Tra & sitio & \\
\hline 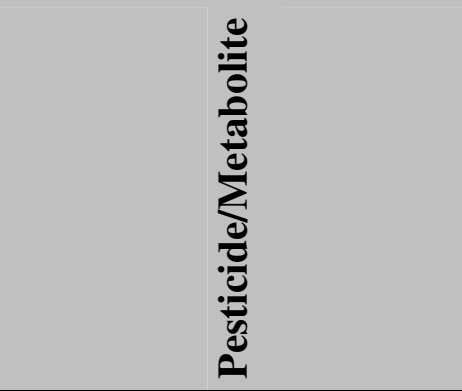 & 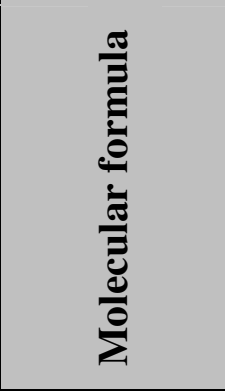 & 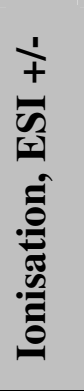 & 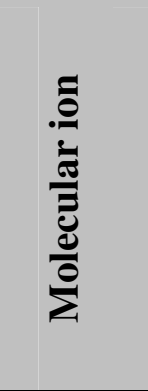 & 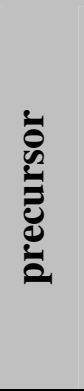 & 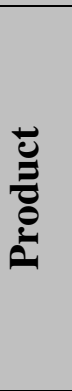 & 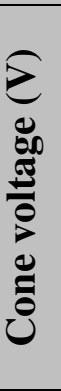 & 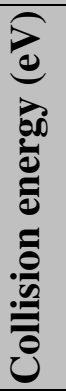 & 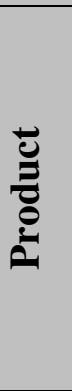 & 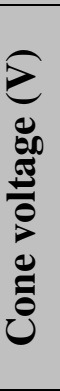 & 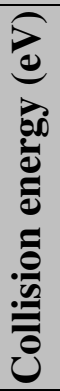 \\
\hline $2,4-D$ & $\mathrm{C}_{8} \mathrm{H}_{6} \mathrm{Cl}_{2} \mathrm{O}_{3}$ & ESI- & {$[\mathrm{M}-\mathrm{H}]-$} & 219 & 161 & 9 & 13 & 125 & 10 & 26 \\
\hline 2-Naphtoxy acetic acid & $\mathrm{C}_{12} \mathrm{H}_{10} \mathrm{O}_{3}$ & ESI- & {$[\mathrm{M}-\mathrm{H}]-$} & 201 & 143 & 45 & 26 & 115 & 45 & 26 \\
\hline 4-Chlorphenoxyacetic acid & $\mathrm{C}_{8} \mathrm{H}_{7} \mathrm{ClO}_{3}$ & ESI- & {$[\mathrm{M}-\mathrm{H}]-$} & 185 & 127 & 24 & 17 & 123 & 24 & 19 \\
\hline Acrinathrin & $\mathrm{C}_{26} \mathrm{H}_{21} \mathrm{~F}_{6} \mathrm{NO}_{5}$ & ESI- & {$[\mathrm{M}-\mathrm{H}]-$} & 540 & 513 & 45 & 11 & & & \\
\hline Acetamiprid & $\mathrm{C}_{10} \mathrm{H}_{11} \mathrm{CIN}_{4}$ & ESI + & {$[\mathrm{M}+\mathrm{H}]+$} & 223 & 126 & 27 & 20 & 90 & 27 & 35 \\
\hline Bentazone & $\mathrm{C}_{10} \mathrm{H}_{12} \mathrm{~N}_{2} \mathrm{O}_{3} \mathrm{~S}$ & ESI- & {$[\mathrm{M}-\mathrm{H}]-$} & 239 & 132 & 38 & 29 & 196 & 38 & 21 \\
\hline Bupirimat & $\mathrm{C}_{13} \mathrm{H}_{24} \mathrm{~N}_{4} \mathrm{O}_{3} \mathrm{~S}$ & ESI + & {$[\mathrm{M}+\mathrm{H}]+$} & 317 & 166 & 27 & 23 & 108 & 25 & 25 \\
\hline Buprofenzin & $\mathrm{C}_{16} \mathrm{H}_{23} \mathrm{~N}_{3} \mathrm{OS}$ & ESI+ & {$[\mathrm{M}+\mathrm{H}]+$} & 306 & 201 & 10 & 11 & 106 & 10 & 23 \\
\hline Clodinafoppropargyl & $\mathrm{C}_{17} \mathrm{H}_{13} \mathrm{ClFNO}_{4}$ & ESI+ & {$[\mathrm{M}+\mathrm{H}]+$} & 350 & 266 & 38 & 17 & 91 & 38 & 20 \\
\hline Clomazone & $\mathrm{C}_{12} \mathrm{H}_{14} \mathrm{CINO}_{2}$ & ESI+ & {$[\mathrm{M}+\mathrm{H}]+$} & 240 & 125 & 10 & 29 & 89 & 10 & 39 \\
\hline Dementon-S-methyl sulfoxid & $\mathrm{C}_{6} \mathrm{H}_{15} \mathrm{O}_{4} \mathrm{PS}_{2}$ & ESI + & {$[\mathrm{M}+\mathrm{H}]+$} & 247 & 169 & 33 & 10 & 127 & 18 & 25 \\
\hline Demeton-S-methyl sulfon & $\mathrm{C}_{6} \mathrm{H}_{15} \mathrm{O}_{5} \mathrm{PS}_{2}$ & ESI + & {$[\mathrm{M}+\mathrm{H}]+$} & 263 & 169 & 55 & 15 & 127 & 45 & 28 \\
\hline Dichlorprop (/Dichlorprop-P) & $\mathrm{C}_{9} \mathrm{H}_{8} \mathrm{Cl}_{2} \mathrm{O}_{3}$ & ESI- & {$[\mathrm{M}-\mathrm{H}]-$} & 233 & 161 & 52 & 17 & 125 & 52 & 26 \\
\hline Dimethomorph & $\mathrm{C}_{21} \mathrm{H}_{22} \mathrm{CINO}_{4}$ & ESI + & {$[\mathrm{M}+\mathrm{H}]+$} & 388 & 301 & 45 & 20 & 165 & 23 & 30 \\
\hline DNOC & $\mathrm{C}_{7} \mathrm{H}_{6} \mathrm{~N}_{2} \mathrm{O}_{5}$ & ESI- & {$[\mathrm{M}-\mathrm{H}]-$} & 197 & 137 & 10 & 17 & 109 & 10 & 20 \\
\hline Epoxiconazole & $\mathrm{C}_{17} \mathrm{H}_{13} \mathrm{ClFN}_{3} \mathrm{O}$ & ESI+ & {$[\mathrm{M}+\mathrm{H}]+$} & 330 & 121 & 45 & 23 & 91 & 45 & 41 \\
\hline Fenazaquin & $\mathrm{C}_{20} \mathrm{H}_{22} \mathrm{~N}_{2} \mathrm{O}$ & ESI+ & {$[\mathrm{M}+\mathrm{H}]+$} & 307 & 161 & 55 & 17 & 131 & 52 & 14 \\
\hline Fluoxastrobin & $\mathrm{C}_{21} \mathrm{H}_{16} \mathrm{CIFN}_{4} \mathrm{O}_{5}$ & ESI+ & {$[\mathrm{M}+\mathrm{H}]+$} & 459 & 427 & 45 & 17 & 188 & 45 & 37 \\
\hline Flusilazole & $\mathrm{C}_{16} \mathrm{H}_{15} \mathrm{~F}_{2} \mathrm{~N}_{3} \mathrm{Si}$ & ESI+ & {$[\mathrm{M}+\mathrm{H}]+$} & 316 & 165 & 51 & 20 & 247 & 20 & 17 \\
\hline Hexythiazox & $\mathrm{C}_{17} \mathrm{H}_{21} \mathrm{CIN}_{2} \mathrm{O}_{2} \mathrm{~S}$ & ESI + & {$[\mathrm{M}+\mathrm{H}]+$} & 353 & 228 & 45 & 11 & 168 & 45 & 27 \\
\hline lodosulfuron-methyl & $\mathrm{C}_{14} \mathrm{H}_{13} \mathrm{IN}_{5} \mathrm{NaO}_{6} \mathrm{~S}$ & ESI+ & {$[\mathrm{M}+\mathrm{H}]+$} & 530 & 163 & 21 & 13 & 390 & 21 & 14 \\
\hline Iprovalicarb & $\mathrm{C}_{18} \mathrm{H}_{28} \mathrm{~N}_{2} \mathrm{O}_{3}$ & ESI+ & {$[\mathrm{M}+\mathrm{H}]+$} & 321 & 119 & 45 & 17 & 91 & 45 & 48 \\
\hline Isoproturon & $\mathrm{C}_{12} \mathrm{H}_{18} \mathrm{~N}_{2} \mathrm{O}$ & ESI+ & {$[\mathrm{M}+\mathrm{H}]+$} & 207 & 72 & 38 & 23 & 165 & 17 & 13 \\
\hline Malaoxon & $\mathrm{C}_{10} \mathrm{H}_{19} \mathrm{O}_{7} \mathrm{PS}$ & ESI + & {$[\mathrm{M}+\mathrm{H}]+$} & 315 & 127 & 48 & 10 & 99 & 33 & 21 \\
\hline MCPA & $\mathrm{C}_{9} \mathrm{H}_{9} \mathrm{ClO}_{3}$ & ESI- & [M-H]- & 199 & 141 & 55 & 11 & 105 & 55 & 26 \\
\hline Mecoprop (/Mecoprop-P) & $\mathrm{C}_{10} \mathrm{H}_{11} \mathrm{ClO}_{3}$ & ESI- & {$[\mathrm{M}-\mathrm{H}]-$} & 213 & 141 & 38 & 23 & 105 & 38 & 28 \\
\hline Metalaxyl -M & $\mathrm{C}_{15} \mathrm{H}_{21} \mathrm{NO}_{4}$ & ESI+ & {$[\mathrm{M}+\mathrm{H}]+$} & 280 & 220 & 52 & 11 & 160 & 52 & 22 \\
\hline Methiocarb sulfoxide & $\mathrm{C}_{11} \mathrm{H}_{15} \mathrm{NO}_{3} \mathrm{~S}$ & ESI+ & {$[\mathrm{M}+\mathrm{H}]+$} & 242 & 185 & 33 & 10 & 122 & 33 & 30 \\
\hline Metsulfuron-methyl & $\mathrm{C}_{14} \mathrm{H}_{15} \mathrm{~N}_{5} \mathrm{O}_{6} \mathrm{~S}$ & ESI+ & {$[\mathrm{M}+\mathrm{H}]+$} & 382 & 167 & 52 & 17 & 135 & 52 & 32 \\
\hline Molinate & $\mathrm{C}_{9} \mathrm{H}_{17} \mathrm{NOS}$ & ESI+ & {$[\mathrm{M}+\mathrm{H}]+$} & 188 & 126 & 52 & 11 & 83 & 30 & 18 \\
\hline Monocrotophos & $\mathrm{C}_{7} \mathrm{H}_{14} \mathrm{NO}_{5} \mathrm{P}$ & ESI + & {$[\mathrm{M}+\mathrm{NH} 4]+$} & 241 & 193 & 21 & 10 & 127 & 10 & 20 \\
\hline Monolinuron & $\mathrm{C}_{9} \mathrm{H}_{11} \mathrm{CIN}_{2} \mathrm{O}_{2}$ & ESI+ & {$[\mathrm{M}+\mathrm{H}]+$} & 215 & 126 & 55 & 17 & 99 & 52 & 30 \\
\hline
\end{tabular}


1

2

3

4

5

6

7

8

9

10

11

12

13

14

15

16

17

18

19

20

21

22

23

24

25

26

27

28

29

30

31

32

33

34

35

36

37

38

39

40

41

42

43

44

45

46

47

48

49

50

51

52

53

54

55

56

57

58

59

60

\begin{tabular}{|c|c|c|c|c|c|c|c|c|c|c|}
\hline \multirow[b]{2}{*}{ 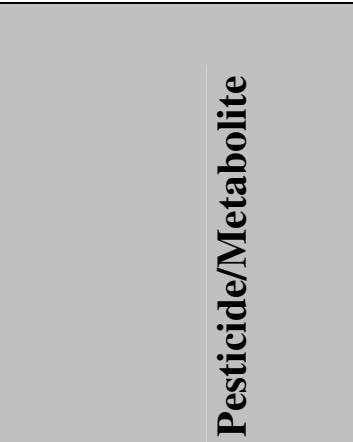 } & \multirow[b]{2}{*}{ 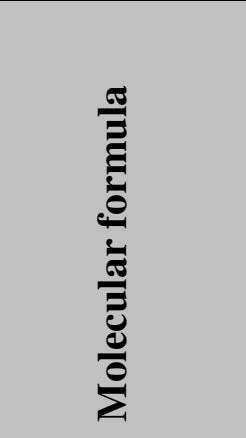 } & \multirow[b]{2}{*}{ 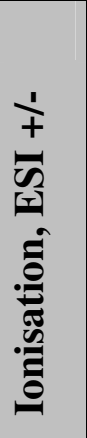 } & \multirow[b]{2}{*}{ 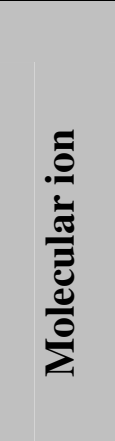 } & \multirow[b]{2}{*}{ 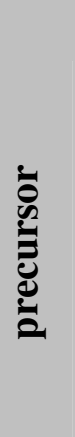 } & \multicolumn{3}{|c|}{ Transition 1} & \multicolumn{3}{|c|}{ Transition 2} \\
\hline & & & & & 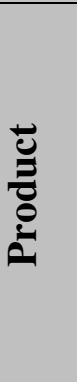 & 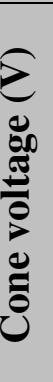 & 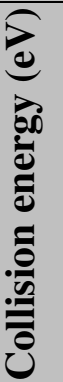 & 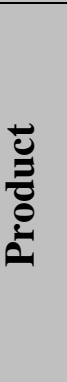 & 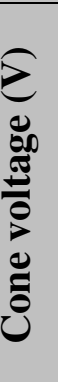 & 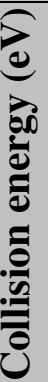 \\
\hline Omethoate & $\mathrm{C}_{5} \mathrm{H}_{12} \mathrm{NO}_{4} \mathrm{PS}$ & ESI+ & {$[\mathrm{M}+\mathrm{H}]+$} & 214 & 183 & 10 & 11 & 143 & 10 & 17 \\
\hline Pirimicarb & $\mathrm{C}_{11} \mathrm{H}_{18} \mathrm{~N}_{4} \mathrm{O}_{2}$ & ESI+ & {$[\mathrm{M}+\mathrm{H}]+$} & 239 & 72 & 25 & 16 & 182 & 25 & 14 \\
\hline Proquinazid & $\mathrm{C}_{14} \mathrm{H}_{17} \mathrm{IN}_{2} \mathrm{O}_{2}$ & $\mathrm{ESI}+$ & {$[\mathrm{M}+\mathrm{H}]+$} & 373 & 331 & 52 & 11 & 289 & 52 & 25 \\
\hline Prosulfuron & $\mathrm{C}_{15} \mathrm{H}_{16} \mathrm{~F}_{3} \mathrm{~N}_{5} \mathrm{O}_{4} \mathrm{~S}$ & ESI+ & {$[\mathrm{M}+\mathrm{H}]+$} & 420 & 141 & 21 & 22 & 167 & & \\
\hline Pyraclostrobin & $\mathrm{C}_{19} \mathrm{H}_{18} \mathrm{CIN}_{3} \mathrm{O}_{4}$ & ESI+ & {$[\mathrm{M}+\mathrm{H}]+$} & 388 & 194 & 24 & 11 & 163 & 24 & 25 \\
\hline Pyridaphenthion & $\mathrm{C}_{14} \mathrm{H}_{17} \mathrm{~N}_{2} \mathrm{O}_{4} \mathrm{PS}$ & $\mathrm{ESI}+$ & {$[\mathrm{M}+\mathrm{H}]+$} & 341 & 189 & 39 & 30 & 205 & 35 & 18 \\
\hline Pyridate & $\mathrm{C}_{19} \mathrm{H}_{23} \mathrm{CIN}_{2} \mathrm{O}_{2} \mathrm{~S}$ & ESI+ & {$[\mathrm{M}+\mathrm{H}]+$} & 379 & 207 & 45 & 17 & 104 & 45 & 30 \\
\hline Pyriproxyfen & $\mathrm{C}_{20} \mathrm{H}_{19} \mathrm{NO}_{3}$ & $\mathrm{ESI}+$ & {$[\mathrm{M}+\mathrm{H}]+$} & 322 & 96 & 55 & 20 & 185 & 27 & 23 \\
\hline Spiroxamin & $\mathrm{C}_{18} \mathrm{H}_{35} \mathrm{NO}_{2}$ & $\mathrm{ESI}+$ & {$[\mathrm{M}+\mathrm{H}]+$} & 298 & 144 & 51 & 20 & 100 & 35 & 30 \\
\hline Thiacloprid & $\mathrm{C}_{10} \mathrm{H}_{9} \mathrm{CIN}_{4} \mathrm{~S}$ & ESI+ & {$[\mathrm{M}+\mathrm{H}]+$} & 255 & 128 & 30 & 20 & & & \\
\hline Thifensulfuron-methyl & $\mathrm{C}_{12} \mathrm{H}_{13} \mathrm{~N}_{5} \mathrm{O}_{6} \mathrm{~S}_{2}$ & ESI- & {$[\mathrm{M}-\mathrm{H}]-$} & 386 & 139 & 31 & 25 & 220 & 31 & 5 \\
\hline Thiodicarb & $\mathrm{C}_{10} \mathrm{H}_{18} \mathrm{~N}_{4} \mathrm{O}_{4} \mathrm{~S}_{3}$ & $\mathrm{ESI}+$ & {$[\mathrm{M}+\mathrm{H}]+$} & 355 & 88 & 27 & 15 & 108 & 27 & 15 \\
\hline Tolylfluanid & $\mathrm{C}_{10} \mathrm{H}_{13} \mathrm{Cl}_{2} \mathrm{FN}_{2} \mathrm{O}_{2} \mathrm{~S}_{2}$ & ESI+ & {$[\mathrm{M}+\mathrm{H}]+$} & 347 & 137 & 40 & 25 & & & \\
\hline Triasulfuron & $\mathrm{C}_{14} \mathrm{H}_{16} \mathrm{CIN}_{5} \mathrm{O}_{5} \mathrm{~S}$ & $\mathrm{ESI}+$ & {$[\mathrm{M}+\mathrm{H}]+$} & 402 & 167 & 52 & 17 & 141 & 52 & 22 \\
\hline Trifloxystrobin & $\mathrm{C}_{20} \mathrm{H}_{19} \mathrm{~F}_{3} \mathrm{~N}_{2} \mathrm{O}_{4}$ & ESI+ & {$[\mathrm{M}+\mathrm{H}]+$} & 409 & 186 & 55 & 17 & 145 & 55 & 45 \\
\hline Triflumuron & $\mathrm{C}_{15} \mathrm{H}_{10} \mathrm{ClF}_{3} \mathrm{~N}_{2} \mathrm{O}_{3}$ & $\mathrm{ESI}+$ & {$[\mathrm{M}+\mathrm{H}]+$} & 359 & 156 & 21 & 25 & 139 & 20 & 30 \\
\hline Patulin & $\mathrm{C}_{7} \mathrm{H}_{6} \mathrm{O}_{4}$ & ESI- & {$[\mathrm{M}-\mathrm{H}]-$} & 153 & 109 & 20 & 12 & 81 & 20 & 17 \\
\hline
\end{tabular}


Table 4. Repeatability, reproducibility, recovery and limits of detection (LOD) at three spiking levels, for pesticides residues in apple.

\begin{tabular}{|c|c|c|c|c|c|c|c|c|c|c|c|}
\hline Spiking concentration, $\mathbf{m g} / \mathbf{k}$ & & 0.02 & 0.04 & 0.2 & $\begin{array}{c}\text { LOQ, } \\
\mathrm{mg} / \mathrm{kg}\end{array}$ & Spiking concentration, $\mathrm{mg} / \mathrm{kg}$ & & 0.02 & 0.04 & 0.2 & $\begin{array}{l}\text { LOQ, } \\
\mathrm{mg} / \mathrm{kg}\end{array}$ \\
\hline 2,4-D & $\begin{array}{l}\operatorname{RSD}_{\mathrm{r}}, \% \\
\mathrm{RSD}_{\mathrm{R}}, \% \\
\text { Recovery, \% }\end{array}$ & & $\begin{array}{r}6 \% \\
7 \% \\
92 \%\end{array}$ & $\begin{array}{c}8 \% \\
11 \% \\
88 \%\end{array}$ & 0.02 & Malaoxon & $\begin{array}{l}\operatorname{RSD}_{\mathrm{r}}, \% \\
\mathrm{RSD}_{\mathrm{R}}, \% \\
\text { Recovery, \% }\end{array}$ & $\begin{array}{c}14 \% \\
14 \% \\
102 \%\end{array}$ & $\begin{array}{l}16 \% \\
22 \% \\
99 \%\end{array}$ & $\begin{array}{c}12 \% \\
12 \% \\
107 \%\end{array}$ & 0.02 \\
\hline Acetamiprid & $\begin{array}{l}\operatorname{RSD}_{\mathrm{r}}, \% \\
\mathrm{RSD}_{\mathrm{R}}, \% \\
\text { Recovery, \% }\end{array}$ & & $\begin{array}{c}23 \% \\
23 \% \\
101 \% \\
\end{array}$ & $\begin{array}{l}19 \% \\
19 \% \\
98 \%\end{array}$ & 0.06 & MCPA & $\begin{array}{l}\operatorname{RSD}_{\mathrm{r}}, \% \\
\mathrm{RSD}_{\mathrm{R}}, \% \\
\text { Recovery, \% }\end{array}$ & $\begin{array}{c}20 \% \\
24 \% \\
101 \% \\
\end{array}$ & $\begin{array}{l}21 \% \\
21 \% \\
70 \%\end{array}$ & $\begin{array}{c}14 \% \\
14 \% \\
107 \% \\
\end{array}$ & 0.03 \\
\hline Acrinathrin & $\begin{array}{l}\mathrm{RSD}_{\mathrm{r}}, \% \\
\mathrm{RSD}_{\mathrm{R}}, \% \\
\text { Recovery, \% }\end{array}$ & $\begin{array}{r}17 \% \\
22 \% \\
128 \% \\
\end{array}$ & $\begin{array}{c}7 \% \\
26 \% \\
105 \% \\
\end{array}$ & $\begin{array}{c}11 \% \\
11 \% \\
107 \% \\
\end{array}$ & 0.03 & Mecoprop & $\begin{array}{l}\mathrm{RSD}_{\mathrm{r}}, \% \\
\mathrm{RSD}_{\mathrm{R}}, \% \\
\text { Recovery, \% }\end{array}$ & $\begin{array}{c}8 \% \\
14 \% \\
94 \% \\
\end{array}$ & $\begin{array}{l}21 \% \\
22 \% \\
80 \% \\
\end{array}$ & $\begin{array}{l}19 \% \\
19 \% \\
89 \%\end{array}$ & 0.01 \\
\hline Bentazone & $\begin{array}{l}\mathrm{RSD}_{\mathrm{r}}, \% \\
\mathrm{RSD}_{\mathrm{R}}, \% \\
\text { Recovery,\% }\end{array}$ & $\begin{array}{c}7 \% \\
7 \% \\
112 \% \\
\end{array}$ & $\begin{array}{c}9 \% \\
17 \% \\
125 \% \\
\end{array}$ & $\begin{array}{c}16 \% \\
17 \% \\
107 \% \\
\end{array}$ & 0.01 & Methalaxyl-M & $\begin{array}{l}\operatorname{RSD}_{\mathrm{r}}, \% \\
\mathrm{RSD}_{\mathrm{R}}, \% \\
\text { Recovery, \% }\end{array}$ & $\begin{array}{l}21 \% \\
21 \% \\
99 \%\end{array}$ & $\begin{array}{c}12 \% \\
20 \% \\
100 \% \\
\end{array}$ & $\begin{array}{c}3 \% \\
8 \% \\
107 \% \\
\end{array}$ & 0.02 \\
\hline Bupirimate & $\begin{array}{l}\mathrm{RSD}_{\mathrm{r}}, \% \\
\mathrm{RSD}_{\mathrm{R}}, \% \\
\text { Recovery, \% }\end{array}$ & 2 & $\begin{array}{l}14 \% \\
14 \% \\
94 \%\end{array}$ & $\begin{array}{c}7 \% \\
31 \% \\
113 \% \\
\end{array}$ & 0.03 & Methiocarb sulfoxid & $\begin{array}{l}\operatorname{RSD}_{\mathrm{r}}, \% \\
\mathrm{RSD}_{\mathrm{R}}, \% \\
\text { Recovery, \% }\end{array}$ & $\begin{array}{c}17 \% \\
27 \% \\
109 \% \\
\end{array}$ & $\begin{array}{l}4 \% \\
19 \% \\
99 \%\end{array}$ & $\begin{array}{l}27 \% \\
27 \% \\
98 \%\end{array}$ & 0.02 \\
\hline Buprofezin & $\begin{array}{l}\operatorname{RSD}_{\mathrm{r}}, \% \\
\mathrm{RSD}_{\mathrm{R}}, \% \\
\text { Recovery, \% }\end{array}$ & $\begin{array}{l}21 \% \\
26 \% \\
89 \%\end{array}$ & $\begin{array}{c}21 \% \\
26 \% \\
103 \% \\
\end{array}$ & $\begin{array}{c}14 \% \\
14 \% \\
117 \% \\
\end{array}$ & 0.03 & Metsulfuron-methyl & $\begin{array}{l}\operatorname{RSD}_{\mathrm{r}}, \% \\
\mathrm{RSD}_{\mathrm{R}}, \% \\
\text { Recovery, \% }\end{array}$ & & $\begin{array}{c}14 \% \\
24 \% \\
104 \% \\
\end{array}$ & $\begin{array}{c}17 \% \\
19 \% \\
121 \% \\
\end{array}$ & 0.05 \\
\hline Demeton-S- methyl Sulfoxid & $\begin{array}{l}\mathrm{RSD}_{\mathrm{r}}, \% \\
\mathrm{RSD}_{\mathrm{R}}, \% \\
\text { Recovery, \% }\end{array}$ & $\begin{array}{l}29 \% \\
29 \% \\
88 \%\end{array}$ & $\begin{array}{l}17 \% \\
20 \% \\
93 \%\end{array}$ & $\begin{array}{c}18 \% \\
18 \% \\
107 \% \\
\end{array}$ & 0.03 & Molinate & $\begin{array}{l}\mathrm{RSD}_{\mathrm{r}}, \% \\
\mathrm{RSD}_{\mathrm{R}}, \% \\
\text { Recovery, \% }\end{array}$ & & $\begin{array}{c}5 \% \\
17 \% \\
104 \% \\
\end{array}$ & $\begin{array}{l}4 \% \\
25 \% \\
92 \% \\
\end{array}$ & 0.04 \\
\hline Demeton-S-methyl Sulfon & $\begin{array}{l}\operatorname{RSD}_{\mathrm{r}}, \% \\
\mathrm{RSD}_{\mathrm{R}}, \% \\
\text { Recovery, \% }\end{array}$ & & $\begin{array}{l}4 \% \\
16 \% \\
87 \%\end{array}$ & $\begin{array}{c}17 \% \\
17 \% \\
106 \% \\
\end{array}$ & 0.03 & Monolinuron & $\begin{array}{l}\operatorname{RSD}_{\mathrm{r}}, \% \\
\mathrm{RSD}_{\mathrm{R}}, \% \\
\text { Recovery, \% }\end{array}$ & $\begin{array}{c}9 \% \\
31 \% \\
107 \%\end{array}$ & $\begin{array}{l}23 \% \\
23 \% \\
96 \%\end{array}$ & $\begin{array}{c}8 \% \\
9 \% \\
108 \% \\
\end{array}$ & 0.04 \\
\hline Dichloprop & $\begin{array}{l}\operatorname{RSD}_{\mathrm{r}}, \% \\
\mathrm{RSD}_{\mathrm{R}}, \% \\
\text { Recovery, \% }\end{array}$ & $\begin{array}{l}11 \% \\
14 \% \\
85 \%\end{array}$ & $\begin{array}{r}8 \% \\
19 \% \\
91 \%\end{array}$ & $\begin{array}{l}18 \% \\
18 \% \\
90 \%\end{array}$ & 0.01 & Omethoate & $\begin{array}{l}\operatorname{RSD}_{\mathrm{r}}, \% \\
\mathrm{RSD}_{\mathrm{R}}, \% \\
\text { Recovery, \% }\end{array}$ & $\begin{array}{c}15 \% \\
19 \% \\
108 \% \\
\end{array}$ & $\begin{array}{l}18 \% \\
35 \% \\
106 \% \\
\end{array}$ & $\begin{array}{c}8 \% \\
14 \% \\
111 \% \\
\end{array}$ & 0.02 \\
\hline Diethofencarb & $\begin{array}{l}\mathrm{RSD}_{\mathrm{r}}, \% \\
\mathrm{RSD}_{\mathrm{R}}, \% \\
\text { Recovery, \% }\end{array}$ & & $\begin{array}{l}19 \% \\
22 \% \\
90 \%\end{array}$ & $\begin{array}{l}26 \% \\
26 \% \\
115 \%\end{array}$ & 0.05 & Pirimicarb & $\begin{array}{l}\mathrm{RSD}_{\mathrm{r}}, \% \\
\mathrm{RSD}_{\mathrm{R}}, \% \\
\text { Recovery, \% }\end{array}$ & $\begin{array}{l}12 \% \\
19 \% \\
94 \%\end{array}$ & $\begin{array}{c}7 \% \\
23 \% \\
89 \%\end{array}$ & $\begin{array}{c}11 \% \\
14 \% \\
117 \% \\
\end{array}$ & 0.02 \\
\hline Fenazaquin & $\begin{array}{l}\operatorname{RSD}_{\mathrm{r}}, \% \\
\mathrm{RSD}_{\mathrm{R}}, \% \\
\text { Recovery, \% }\end{array}$ & $\begin{array}{l}26 \% \\
26 \% \\
75 \%\end{array}$ & $\begin{array}{l}18 \% \\
21 \% \\
93 \%\end{array}$ & $\begin{array}{c}17 \% \\
18 \% \\
107 \% \\
\end{array}$ & 0.02 & Pyraclostrobin & $\begin{array}{l}\operatorname{RSD}_{\mathrm{r}}, \% \\
\mathrm{RSD}_{\mathrm{R}}, \% \\
\text { Recovery, \% }\end{array}$ & $\begin{array}{c}18 \% \\
18 \% \\
109 \% \\
\end{array}$ & $\begin{array}{c}24 \% \\
24 \% \\
105 \% \\
\end{array}$ & $\begin{array}{c}9 \% \\
9 \% \\
112 \% \\
\end{array}$ & 0.02 \\
\hline Flusilazole & $\begin{array}{l}\mathrm{RSD}_{\mathrm{r}}, \% \\
\mathrm{RSD}_{\mathrm{R}}, \% \\
\text { Recovery, \% }\end{array}$ & & & $\begin{array}{c}8 \% \\
11 \% \\
99 \% \\
\end{array}$ & 0.14 & Pyriproxyfen & $\begin{array}{l}\operatorname{RSD}_{\mathrm{r}}, \% \\
\mathrm{RSD}_{\mathrm{R}}, \% \\
\text { Recovery, \% }\end{array}$ & $\begin{array}{c}13 \% \\
15 \% \\
105 \% \\
\end{array}$ & $\begin{array}{c}6 \% \\
20 \% \\
130 \% \\
\end{array}$ & $\begin{array}{c}14 \% \\
14 \% \\
120 \% \\
\end{array}$ & 0.02 \\
\hline Hexythiazox & $\begin{array}{l}\mathrm{RSD}_{\mathrm{r}}, \% \\
\mathrm{RSD}_{\mathrm{R}}, \% \\
\text { Recovery, \% }\end{array}$ & & & $\begin{array}{c}20 \% \\
20 \% \\
117 \% \\
\end{array}$ & 0.28 & Spiroxamine & $\begin{array}{l}\operatorname{RSD}_{\mathrm{r}}, \% \\
\mathrm{RSD}_{\mathrm{R}}, \% \\
\text { Recovery, \% }\end{array}$ & $\begin{array}{l}16 \% \\
17 \% \\
93 \% \\
\end{array}$ & $\begin{array}{l}16 \% \\
25 \% \\
90 \% \\
\end{array}$ & $\begin{array}{c}16 \% \\
16 \% \\
113 \% \\
\end{array}$ & 0.02 \\
\hline Iprovalicarb & $\begin{array}{l}\mathrm{RSD}_{\mathrm{r}}, \% \\
\mathrm{RSD}_{\mathrm{R}}, \% \\
\text { Recovery, \% }\end{array}$ & $\begin{array}{c}2 \% \\
20 \% \\
112 \% \\
\end{array}$ & $\begin{array}{l}17 \% \\
18 \% \\
92 \%\end{array}$ & $\begin{array}{c}18 \% \\
18 \% \\
114 \% \\
\end{array}$ & 0.02 & Thiodicarb & $\begin{array}{l}\mathrm{RSD}_{\mathrm{r}}, \% \\
\mathrm{RSD}_{\mathrm{R}}, \% \\
\text { Recovery, \% }\end{array}$ & $\begin{array}{l}19 \% \\
19 \% \\
65 \%\end{array}$ & $\begin{array}{l}24 \% \\
28 \% \\
96 \%\end{array}$ & $\begin{array}{c}11 \% \\
11 \% \\
103 \% \\
\end{array}$ & 0.01 \\
\hline Isoproturon & $\begin{array}{l}\mathrm{RSD}_{\mathrm{r}}, \% \\
\mathrm{RSD}_{\mathrm{R}}, \% \\
\text { Recovery, \% }\end{array}$ & $\begin{array}{c}19 \% \\
19 \% \\
104 \%\end{array}$ & $\begin{array}{l}28 \% \\
28 \% \\
99 \%\end{array}$ & $\begin{array}{c}16 \% \\
16 \% \\
110 \%\end{array}$ & 0.02 & Triflumuron & $\begin{array}{l}\mathrm{RSD}_{\mathrm{r}}, \% \\
\mathrm{RSD}_{\mathrm{R}}, \% \\
\text { Recovery, \% }\end{array}$ & $\begin{array}{l}28 \% \\
30 \% \\
78 \%\end{array}$ & $\begin{array}{c}4 \% \\
54 \% \\
109 \% \\
\end{array}$ & $\begin{array}{c}20 \% \\
20 \% \\
113 \% \\
\end{array}$ & 0.03 \\
\hline
\end{tabular}


Table 5. Mean recovery and standard deviation for patulin, trifloxystrobin, tolylfluanid, thiacloprid, flusilazole and pirimicarb in apples.

\begin{tabular}{|c|c|c|c|c|}
\hline \multirow[b]{2}{*}{ Patulin } & \multicolumn{3}{|c|}{ Spiking level, mg/kg } & \multirow{2}{*}{$\begin{array}{c}\mathrm{LOQ} \\
\mathrm{mg} / \mathrm{kg}\end{array}$} \\
\hline & 0.02 & 0.04 & 0.2 & \\
\hline Mean & $86 \%$ & $105 \%$ & $101 \%$ & \\
\hline \multirow[t]{2}{*}{ Standard dev. } & $8 \%$ & $22 \%$ & $26 \%$ & 0.04 \\
\hline & \multicolumn{3}{|c|}{ Spiking level, mg/kg } & LOQ \\
\hline Trifloxystrobin & 0.02 & 0.04 & 0.2 & $\mathrm{mg} / \mathrm{kg}$ \\
\hline Mean & $84 \%$ & $86 \%$ & $89 \%$ & \\
\hline \multirow[t]{2}{*}{ Standard dev. } & $9 \%$ & $9 \%$ & $7 \%$ & 0.01 \\
\hline & \multicolumn{3}{|c|}{ Spiking level, mg/kg } & LOQ \\
\hline Tolylfluanid & 0.02 & 0.04 & 0.2 & $\mathrm{mg} / \mathrm{kg}$ \\
\hline Mean & $69 \%$ & $87 \%$ & $109 \%$ & \\
\hline \multirow[t]{2}{*}{ Standard dev. } & $19 \%$ & $23 \%$ & $20 \%$ & 0.02 \\
\hline & \multicolumn{3}{|c|}{ Spiking level, mg/kg } & LOQ \\
\hline Thiacloprid & 0.02 & 0.04 & 0.2 & $\mathrm{mg} / \mathrm{kg}$ \\
\hline$\overline{\text { Mean }}$ & $86 \%$ & $92 \%$ & $90 \%$ & \\
\hline \multirow[t]{2}{*}{ Standard dev. } & $13 \%$ & $21 \%$ & $11 \%$ & 0.02 \\
\hline & \multicolumn{3}{|c|}{ Spiking level, mg/kg } & LOQ \\
\hline Flusilazole & 0.02 & 0.04 & 0.2 & $\mathrm{mg} / \mathrm{kg}$ \\
\hline$\overline{M e a n}$ & $91 \%$ & $81 \%$ & $86 \%$ & \\
\hline \multirow[t]{2}{*}{ Standard dev. } & $13 \%$ & $6 \%$ & $14 \%$ & 0.02 \\
\hline & \multicolumn{3}{|c|}{ Spiking level, mg/kg } & LOQ \\
\hline Pirimicarb & 0.02 & 0.04 & 0.2 & $\mathrm{mg} / \mathrm{kg}$ \\
\hline Mean & $96 \%$ & $97 \%$ & $97 \%$ & \\
\hline Standard dev. & $4 \%$ & $15 \%$ & $4 \%$ & 0.005 \\
\hline
\end{tabular}


Table 6. Patulin content in apples treated with pesticides at different times before harvest. Both the non-inoculated and the samples inoculated with $P$. expansum were investigated after 28 days of shelf-life

\begin{tabular}{|c|c|c|c|}
\hline Pesticide treatment & $\begin{array}{l}\text { Patulin content } \\
(\mathrm{mg} / \mathrm{kg}) \text { in non } \\
\text { inoculated } \\
\text { samples }\end{array}$ & $\begin{array}{l}\text { Patulin content in core } \\
\text { inoculated samples } \\
(\mathrm{mg} / \mathrm{kg})\end{array}$ & $\begin{array}{c}\text { Patulin content in surface } \\
\text { inculated samples } \\
(\mathrm{mg} / \mathrm{kg})\end{array}$ \\
\hline Untreated & $\begin{array}{c}<0.02 \\
(-)\end{array}$ & $\begin{array}{c}15.4 \\
(+)\end{array}$ & $\begin{array}{l}4.1 \\
(+)\end{array}$ \\
\hline $\begin{array}{l}\text { Treated with pesticides } \\
4 \text { weeks before harvest }\end{array}$ & $\begin{array}{c}<0.02 . \\
(-)\end{array}$ & not determined & not determined \\
\hline $\begin{array}{l}\text { Treated with pesticides } \\
2 \text { weeks before harvest }\end{array}$ & $\begin{array}{c}<0.02 . \\
(-)\end{array}$ & $\begin{array}{l}8.7 \\
(+)\end{array}$ & $\begin{array}{l}4.3 \\
(+)\end{array}$ \\
\hline $\begin{array}{l}\text { Treated with pesticides } \\
1 \text { week before harvest }\end{array}$ & $\begin{array}{c}<0.02 \\
(-)\end{array}$ & $\begin{array}{c}15.2 \\
(+)\end{array}$ & $\begin{array}{l}2.7 \\
(+)\end{array}$ \\
\hline
\end{tabular}

